\title{
Effect of anionic salts and potassium intake on some blood and urine minerals and acid-base balance of dry pregnant cows on grass silage based feeding *
}

\author{
S. Tauriainen ${ }^{1}$, S. Sankari ${ }^{2}$, S. Pyörälä ${ }^{2}$ and L. Syrjälä-Qvist ${ }^{1}$ \\ University of Helsinki \\ ${ }^{i}$ Department of Animal Science \\ FIN-00014 University of Helsinki, Finland \\ 'Department of Clinical Veterinary Sciences \\ Hämeentie 57, P.O. Box 6 \\ FIN-00581 Helsinki, Finland
}

(Received 20 September 2000; accepted 22 January 2001)

\begin{abstract}
Twenty-one Ayshire cows were randomly assigned to one of three diets to determine the cffect of an anjonic diet and high potassium $(\mathrm{K})$ intake on mincral metabolism, acid-base status and feed intake of dairy cows fed grass silage based diets during the dry period. Dietary cation-anion balance (DCAB), calculated as milliequivalents $\left[\left(\mathrm{Na}^{+}+\mathrm{K}^{+}\right)-\left(\mathrm{Cl}+\mathrm{S}^{2-}\right)\right]$, for high DCAB (control), high DCAB + K-supplement (added as $\mathrm{KHCO}_{3}$ ) and low DCAB treatments were +298 , +571 and $+107 \mathrm{mEq} / \mathrm{kg} \mathrm{DM}$, respectively. Dietary magnesium $(\mathrm{Mg})$ content, equivalent to a daily $\mathrm{Mg}$ intake of $33 \mathrm{~g}$, was on average $0.4 \%$ (in a DM basis). Cows received grass silage (5.2 $\mathrm{kg} \mathrm{DM}$ ), hay $(0.9 \mathrm{~kg}$ DM) and concentrate mixture $(2.7 \mathrm{~kg} \mathrm{DM})$ until calving. Blood and urine samples were collected 4, 3, 2 and 1 week before the expected calving date, at calving, the day and 1 week after calving. Only urinary $\mathrm{pH}$ was significantly affected by a low DCAB prepartum. K supplementation decreased fractional excretion of $\mathrm{Mg}$ and $\mathrm{Na}$ in the urine and significantly increased prepartum urinary $\mathrm{K}$ excretion. A dietary $\mathrm{K}$ concentration of $34 \mathrm{~g} / \mathrm{kg}$ DM coupled with a high $\mathrm{Mg}$ intake of $4 \mathrm{~g} / \mathrm{kg} \mathrm{DM}$ in the prepartum diet may negatively effect $\mathrm{Mg}$ metabolism after parturition.
\end{abstract}

KEY WORDS: calcium, cows, ion balance, minerals, parturient paresis, potassium

\footnotetext{
* Supported by the A. Kordelin foundation and Rehuraisio Ltd.
} 


\section{INTRODUCTION}

Acidic diets have been successfully used to prevent parturient hypocalcaemia in dairy cows (Block, 1984; Oetzel et al., 1988; Goff et al., 1991). When a low dictary cation anion balance (DCAB) has been fed to dry cows, the blood calcium (Ca) concentration has remained more stable around parturition relative to high DCAB diets (Wang and Beede, 1992; Abu Damir et al., 1994; Phillippo et al., 1994). In most studies of DCAB feeding, diets have been formulated as a total mixed ration (TMR) (Block, 1984; Goff et al., 1991; Goff and Horst, 1997). However, in Finland concentrates and forages are traditionally fed separately, and the use of low DCAB diets has not been used for the prevention of parturient hypocalcaemia. In previous studies (Tauriainen et al., 1998a,b,c) a concentrate mixture which contained anionic salts for dry cows has been evaluated in cows fed a grass silage based diet with a relatively high potassium (K) content (mean $30 \mathrm{~g} / \mathrm{kg}$ dry matter, DM). It appears that the development of a suitable concentrate mixture which would balance the high cationic load of grass silage, having a high palatability, and also would be effective and safe is difficult.

Goff and Horst (1997) found that dictary K concentration of $21 \mathrm{~g}$ and $31 \mathrm{~g} / \mathrm{kg}$ DM increased the incidence of parturient hypocalcaemia compared with diets containing $11 \mathrm{~g} / \mathrm{kg} \mathrm{DM}$. On this basis, it was suggested that dietary Ca concentration is not a major risk factor for parturient hypocalcaemia, but reactive cations such as $\mathrm{K}$ could induce metabolic alkalosis in the prepartum dairy cow, which has a detrimental influence on Ca homeostasis. Between 1996 and 1999 the mean $\mathrm{K}$ content of grass silage and pre-wilted grass silage in Finland has been 21 and $25 \mathrm{~g} / \mathrm{kg} \mathrm{DM}$, respectivcly (Nousiainen, 2000). In some farms the $\mathrm{K}$ content of grass silage, particularly after wilting, can be as high as $50 \mathrm{~g} / \mathrm{kg} \mathrm{DM}$, corresponding to a total dietary $\mathrm{K}$ concentration of between 35 and $45 \mathrm{~g} / \mathrm{kg} \mathrm{DM}$. Cows fed such diets could be predisposed to hypocalcaemia and parturient hypocalcaemia.

Udder oedema has been reported postpartum, when $15 \mathrm{~g} / \mathrm{kg} \mathrm{DM}$ of $\mathrm{CaCl}_{2}$ was offered compared to $22 \mathrm{~g} / \mathrm{kg}$ DM of limestone 3 weeks before expected calving date to Holstein heifers (Lema et al., 1992). Dietary inclusion of $\mathrm{NaCl}$ or $\mathrm{KHCO}_{3}$ from $45 \mathrm{~d}$ prepartum to $10 \mathrm{~d}$ postpartum has been shown to increase the severity of udder oedema, but addition of both salts had no influence (Nestor et al., 1988). Supplemental $\mathrm{NaCl}(227 \mathrm{~g} / \mathrm{d}), \mathrm{KCl}(227 \mathrm{~g} / \mathrm{d})$ or both 30 days prepartum resulted in a greater incidence of oedema than non-supplemented diets (Randall et al., 1974). Reports on the possible relationship between udder oedema and DCAB are limited and tended to be conflicting. According to Kiess et al. (1987), the incidence of udder oedema was not significantly correlated with DCAB. However, Tucker et al. (1991) found that udder oedema regressed postpartum more rapidly in cows previously fed a low DCAB $(-30 \mathrm{mEq} / \mathrm{kg} \mathrm{DM})$ relative to cows 
fed a high DCAB (+90 mEq/kg DM). In an earlier study (Tauriainen et al., 1998a) severe udder oedema was unexpectedly observed in a high proportion of cows when the DCAB was $-247 \mathrm{mEq} / \mathrm{kg}$ DM, but the incidence was not routinely evaluated and as such these findings were not documented.

The current experiment was conducted in order to assess the effect of anionic salts and high dietary $\mathrm{K}$ content on some blood and urinary mineral concentrations. Since earlier studies (Tauriainen et al., 1998bc) have indicated that recommended magnesium $(\mathrm{Mg})$ intakes $(14 \mathrm{~g} / \mathrm{d})$ for dry cows may be too low, $\mathrm{Mg}$ intakes in the current study were increased to a higher level $(33 \mathrm{~g} / \mathrm{d})$. The potential influence of anionic salts in the concentrate mixture or supplemental $\mathrm{K}$ in the diet on the degree of udder oedema was also monitored.

\section{MATERIAL AND METHODS}

\section{Experimental design and treatments}

Twenty-one multiparous Finnish Ayrshire cows (age $48 \pm 14$ months) and no history of parturient paresis from previous lactations were selected from the research herd of the University of Helsinki. Cows weighed $638 \pm 58 \mathrm{~kg}$ at the beginning of the trial, and were randomly allocated to one of three dietary treatments with 7 cows per diet. Cows were fed grass silage $(5.2 \mathrm{~kg} \mathrm{DM} / \mathrm{d})$, hay $(0.9 \mathrm{~kg} \mathrm{DM} / \mathrm{d})$ and concentrate treatments $(2.7 \mathrm{~kg} \mathrm{DM} / \mathrm{d})$. The experimental feeding period started 4 weeks prior to expected calving date of each cow and ended at parturition. Immediately after calving, cows entered the routine nutrition and management program adopted at the research farm of the University of Helsinki.

Experimental diets were: Diet 1, high DCAB (control), Diet 2, high DCAB and $\mathrm{K}$ supplement fed as $\mathrm{KHCO}_{3}$, and Diet 3, low DCAB. Cows were divided into two blocks according to age ( 2 nd parity and $>2$ nd parity). Within each block cows were randomly assigned to one of three treatments in groups according to the expected calving date. The low DCAB dict contained additional chlorine (Cl) and sulphur (S), supplied primarily by adding chlorides of ammonium and magnesium, and magnesium sulphate. Anionic salts were included in the concentrate mixture that was subsequently pelleted (diameter $5 \mathrm{~mm}$ ). Composition of experimental diets and concentrate mixtures are shown in Table 1. Using the formula $\left(\mathrm{Na}^{+}+\mathrm{K}^{+}\right)-\left(\mathrm{Cl}^{-}+\mathrm{S}^{2-}\right) \mathrm{mEq} / \mathrm{kg} \mathrm{DM}$, the control, high DCAB and low DCAB diets contained $+298,+571$ and $+107 \mathrm{mEq} / \mathrm{kg}$ DM, respectively. Sulphur was included to avoid an excessive $\mathrm{Cl}^{-}$content, since the effect of $\mathrm{S}^{2-}$ on the systemic acid-base status in lactating cows has been reported to be similar to that of $\mathrm{Cl}^{-}$(Tucker et al., 1991). The high $\mathrm{K}$ level was achieved by dietary inclusion 
TABLE 1

Formulation of experimental diets ${ }^{1}$

\begin{tabular}{|c|c|c|c|}
\hline \multirow{2}{*}{ Ingredient, $1 \%$} & \multicolumn{3}{|c|}{ Concentrate } \\
\hline & control & high $\mathrm{DCAB}^{2}$ & low DCAB \\
\hline Oat & 27.77 & & \\
\hline Wheat-protein & 20.85 & 19.88 & 17.95 \\
\hline Oat bran & 16.06 & 13.70 & 17.42 \\
\hline Barley & 14.59 & 9.74 & 12.08 \\
\hline Wheat molasses & 7.24 & 7.15 & 7.33 \\
\hline $\mathrm{CaCO}_{3}$ & 4.85 & 4.79 & 4.14 \\
\hline $\mathrm{MgPO}_{4}$ & 3.55 & 3.62 & - \\
\hline $\mathrm{NaCl}$ & 0.65 & 0.64 & 0.65 \\
\hline $\mathrm{KHCO}_{3}$ & - & 10.62 & - \\
\hline $\mathrm{CaPO}_{4}$ & - & - & 2.14 \\
\hline $\mathrm{NH}_{4} \mathrm{Cl}$ & - & - & 2.18 \\
\hline $\mathrm{MgCl}_{2}$ & - & - & 1.84 \\
\hline $\mathrm{MgSO}_{4}$ & - & - & 1.95 \\
\hline Flavour premix & 2.98 & 3.93 & 4.73 \\
\hline Plant oil & 0.56 & 0.55 & 0.57 \\
\hline Selenium mix & 0.50 & 0.49 & 0.51 \\
\hline Vitamin mix & 0.20 & 0.20 & 0.20 \\
\hline Trace element mix & 0.20 & 0.20 & 0.20 \\
\hline \multicolumn{4}{|l|}{ Dietary inclusion, $\%$} \\
\hline grass silage & 59.16 & 59.00 & 59.12 \\
\hline hay & 10.35 & 10.36 & 10.35 \\
\hline concentrate mixture & 30.49 & 30.64 & 30.53 \\
\hline
\end{tabular}

dry matter basis

2 dietary cation-anion balance

of $\mathrm{KHCO}_{3}$. According to Schonewille et al. (1999) added and intrinsic $\mathrm{K}$ have the same effects at least on ruminal $\mathrm{K}$ concentrations and $\mathrm{Mg}$ absorption from the rumen. Chemical composition of experimental diets is documented in Table 2.

Cows were housed and fed in individual tie stalls with free access to drinking water. Grass silage was offered twice daily $(0530$ and $1400 \mathrm{~h})$ and hay and concentrates once daily $(1430 \mathrm{~h})$. In case of refused feed, refusals were weighed and the dry matter content was determined. Samples of grass silage, hay and concentrate collected each week were pooled; grass silage was combined into monthly samples and hay into bales, and frozen. Grass silage DM was determined weekly by drying at $100^{\circ} \mathrm{C}$ for $24 \mathrm{~h}$.

Cows were weighed and body condition was scored at the beginning of the experiment, two weeks later and after calving. Body condition was assessed on a scale from 1 to 5 , where 1 represented extremely thin and 5 represented extremely obese animals (Windman et al., 1982). 
TABLE 2

Dry matter intake, energy content, chemical composition' and cation-anion balance of experimental dicts

\begin{tabular}{lrcc}
\hline & Control & High DCAB & Low DCAB \\
\hline $\mathrm{DMl}^{3} \mathrm{~kg} / \mathrm{d}$ & 8.79 & 8.79 & 8.79 \\
$\mathrm{ME}^{4} \mathrm{MJ} / \mathrm{kg} \mathrm{DM}$ & 9.70 & 9.71 & 9.46 \\
Crude protein, \% & 14.22 & 14.08 & 14.61 \\
Crude fibre, \% & 25.11 & 24.67 & 24.85 \\
ADF $\%$ & 31.33 & 24.02 & 24.18 \\
$\mathrm{NDF}^{6} \%$ & 47.03 & 45.91 & 45.89 \\
$\mathrm{Ca} \%$ & 0.86 & 0.85 \\
$\mathrm{P} \%$ & 0.78 & 0.44 & 0.42 \\
$\mathrm{Mg}, \%$ & 0.43 & 0.41 & 0.34 \\
$\mathrm{~K}, \%$ & 0.38 & 3.42 & 2.52 \\
$\mathrm{Na} \%$ & 0.16 & 0.14 \\
$\mathrm{Cl} \% \%$ & 2.37 & 0.68 & 1.34 \\
S, \% & 0.14 & 0.29 & 0.35 \\
$\mathrm{DCAB}^{7} \mathrm{mEg} / \mathrm{kg} \mathrm{DM}$ & 0.67 & +571 & +107 \\
\hline
\end{tabular}

1 expressed on a dry matter (DM) basis

2 dictary cation-anion balance

${ }^{3}$ dry matter intake

${ }^{4}$ metabolizable energy calculated according to MAFF (1975)

$s$ acid detergent fibre

"neutral detcrgent fibre

7 dietary cation-anion balance calculated as milliequivalents $\left(\mathrm{Na}^{+}+\mathrm{K}^{+}\right)-\left(\mathrm{Cl}+\mathrm{S}^{2}\right)$ per $\mathrm{kg} \mathrm{DM}$

Udder ocdema was evaluated by measuring the vertical height from the hind udder attachment to the root of the hind teat and the horizontal width from the outer edge of the udder to the central ligament and marking a cross at the intersection of these lines. Measurements were performed from the centre of the cross to the central ligament and the root of rear teat of each side of the udder. Evaluation was done in the beginning of the experiment, two weeks later, at parturition and one week after calving.

\section{Sample collection}

Blood from jugular vein and urine samples were collected before afternoon feeding, 4, 3, 2, and 1 week prepartum, on the day of calving, and 1 and 7 days postpartum. Two samples were collected into $5 \mathrm{ml}$ evacuated heparinized tubes (Venoject VT-050 SHL, Terumo Europe N.V., Leuven, Belgium). The first was centrifuged $(1000 \mathrm{~g}$ for $8 \mathrm{~min})$ immediately after sampling and the resultant plasma was stored frozen $\left(-20^{\circ} \mathrm{C}\right)$ for $\mathrm{Na}^{+}, \mathrm{K}^{+}, \mathrm{Cl}^{-}$, total $\mathrm{Ca}, \mathrm{Mg}, \mathrm{P}$ and creatinine deter- 
minations. The second was stored frozen $\left(-20^{\circ} \mathrm{C}\right)$ for haemoglobin measurements. An additional sample was collected into a $2-\mathrm{ml}$ syringe containing Ca-stabilized heparin (Pico 50, Radiometer Copenhagen) for measurements of acid-base status. Syringes were placed on ice after sampling. After an immediate determination of blood gases in whole blood, the remainder of the sample was used for measurements of ionized $\mathrm{Ca}$ and $\mathrm{Mg}$ concentrations. Cow body temperature was measured before each blood sampling with a metal thermometer.

Urine samples were collected by manual stimulation of the vulva and were frozen prior to $\mathrm{pH}$, creatinine and $\mathrm{P}$ determinations. Five $\mathrm{ml}$ of urine were transferred into a tube containing $0.5 \mathrm{ml}$ of $12 \mathrm{~N} \mathrm{HCl}$ and frozen for subsequent of total $\mathrm{Ca}, \mathrm{Mg}, \mathrm{K}$ and $\mathrm{Na}$ determinations.

Analyses

Blood $\mathrm{pH}$, partial pressure of $\mathrm{CO}_{2}\left(\mathrm{pCO}_{2}\right)$ and acid-base excess were measured using a blood gas analyser (ABL3 Acid-Base Laboratory, Radiometer A/S, Copenhagen, Denmark). Measurements of $\mathrm{pH}$ and $\mathrm{pCO}_{2}$ were corrected for measured body temperature for each cow according to the manufacturer instructions. Corrected $\mathrm{pH}$ and $\mathrm{pCO}_{2}$ values were subsequently used to calculate true bicarbonate $\left(\mathrm{aHCO}_{3}\right)$ and base excess $(\mathrm{BE})$ values.

Plasma and urinary $\mathrm{Ca}$ and $\mathrm{Mg}$ concentrations were assessed by an atomic absorption spectrophotometer (Model 2380, Perkin Elmer Corp., Norwalk, Conn., USA), and creatinine concentrations were determined using an automated kinetic alkaline picrate method (Fabiny and Ertigshausen, 1971). Inorganic phosphorus in plasma was determined based on the colorimetric method of Daly and Ertigshausen (1972). Concentrations of $\mathrm{Na}^{+}, \mathrm{K}^{+}$and $\mathrm{Cl}^{-}$in plasma (KONE Microlyte $3+2$, KONE Corp., Espoo, Finland) and ionized $\mathrm{Ca}$ and $\mathrm{Mg}$ in whole blood (Microlyte 6 Ion Selective Analyser, Konelab Corp., Espoo, Finland) were analysed using ion-specific electrodes.

Concentrations of $\mathrm{Na}$ and $\mathrm{K}$ in urine were determined using a flame photometer (Corning 480, Ciba Corning Diagnostics Limited, Halstead, UK). Urinary $\mathrm{pH}$ was measured with a $\mathrm{pH}$ meter (Radiometer Copenhagen, PHM 83 Autocal $\mathrm{pH}$ meter). Fractional excretion $\left(\mathrm{FE}_{\mathrm{x}}\right)$ of elcctrolytes $(\mathrm{x})$ was calculated as:

$$
\mathrm{FE}_{\mathrm{x}}, \%=\mathrm{x}_{\mathrm{u}} \times \text { creatinine }_{\mathrm{p}} / \mathrm{x}_{\mathrm{p}} \times \text { creatinine }_{\mathrm{u}} \times 100
$$

where $u$ refers to urinary electrolyte concentration, and $p$ to the corresponding concentration in plasma.

The $\mathrm{Cl}$ content of grass silage was determined according to standard procedures (AOAC, 1984). Chemical composition of feeds was measured according to previously reported methods (Tauriainen et al., 1998a). 


\section{Statistical analysis}

Experimental data was analysed in two parts; prepartum from 4 weeks to 1 week before the expected calving date and peripartum from 1 week before expected calving to 1 week after calving. Plasma and urinary data was analysed by repeated measures analysis of variance using the SAS (1985) general linear model procedure for a complete block design that included the following model:

$$
Y_{i j .}=\mu+T_{i}+P_{j}+e_{i j}
$$

where $\mu$ is the general mean, $T_{i}$ is the effect of treatment $i, \mathrm{P}_{\mathrm{j}}$ is effect of parity $j$ and $e_{i j}$ the error term.

Because there was no interaction between treatments and parity, this interaction term was subsequently excluded from the model. Treatment differences were evaluated using the Tukey test. Residuals of all data within dietary treatments were assessed for normality (Shapiro-Wilk test). Because preliminary analysis of raw data indicated heterogeneous variance for urinary $\mathrm{Ca} /$ creatinine and $\mathrm{P} /$ creatinine rations and fractional $\mathrm{Na}$ and $\mathrm{Mg}$ excretion, these variables were logarithmically transformed to achieve a more homogeneous variance. An one-way analysis of variance of the three treatment groups was performed for data collected at 4 weeks before the expected calving date to assess initial differences between experimental groups. Due to significant $(\mathrm{P}<0.05)$ differences between $\mathrm{Mg} /$ creatinine at the start of the trial, pre-treatment values were used as covariates. Udder oedema data was analysed by week using least squares analysis of variance, following the general linear models procedure. The statistical model was:

$$
\mathrm{Y}_{\mathrm{ij},}=\mu+\mathrm{T}_{\mathrm{i}}+\mathrm{P}_{\mathrm{j}}+\mathrm{e}_{\mathrm{ij}}
$$

where $\mu$ is the general mean, $\mathrm{T}_{\mathrm{i}}$ is the effect of treatment $i, \mathrm{P}_{\mathrm{j}}$ is effect of parity $j$ and $\mathrm{e}_{\mathrm{ij}}$ the error term.

For the vertical height measures of udder oedema, initial values were used as a covariate. For all analysis $\mathrm{P}<0.05$ was considered to reflect significant differences.

\section{RESULTS}

Cows were fed a fixed ration throughout the experiment. Palatability of all experimental concentrates was good with no refusals, leading to similar intake between treatments (Table 2). The mean body condition of all cows at parturition was 3.3 , indicating that the slightly lower feeding level than that recommended in Finland during the dry period (Tuori et al., 1996) had no visible adverse effects on the cows. No significant udder oedema was identified during the entire trial for any of the treatment groups. 
A lowered cation-anion balance had no effect on measured blood parameters (Table 3). One of the cows in K-supplement group showed clinical signs of parturient hypocalcaemia around parturition and was treated with a $\mathrm{Ca}$ infusion after blood sampling $\left(\mathrm{Ca}^{2+} 0.74 \mathrm{mmol} / \mathrm{l}\right)$. Two cows in the low DCAB group and one cow in the $\mathrm{K}$-supplement group had a low blood $\mathrm{Ca}$ level $\left(\mathrm{Ca}^{2+}<1.00 \mathrm{mmol} /\right.$ 1) at parturition. Cows calving for the second time had a significantly lower $(\mathrm{P}<0.05)$ plasma Ca concentration prepartum compared with multiparous cows, although at parturition the mean value for older cows was lower. Total plasma $\mathrm{Mg}$ and blood ionized $\mathrm{Mg}$ were not affected by treatments, but five cows from the K-supplement group and one cow in the low DCAB group were found to have subclinical hypomagnesaemia one week after parturition indicated by a plasma Mg below $0.85 \mathrm{mmol} / \mathrm{l}$ (Samson et al., 1983). The lowest mean plasma $\mathrm{Mg}$ concentration $(0.80 \mathrm{mmol} / \mathrm{l})$ was observed for the K-supplement group one week after calving (Table 3). Concentrations of total $\mathrm{Ca}$, inorganic $\mathrm{P}, \mathrm{Na}$ and $\mathrm{Cl}$ in plasma were unaffected by $\mathrm{K}$-supplementation during the trial, but plasma $\mathrm{K}$ concentrations tended to be higher prepartum and lower on the day of calving than that of other treatment groups. Blood $\mathrm{Ca}^{2+}$ and plasma inorganic $\mathrm{P}, \mathrm{Na}^{\prime}, \mathrm{K}^{+}$ and $\mathrm{Cl}^{-}$did not differ between treatment groups. Blood $\mathrm{pH}, \mathrm{HCO}_{3}{ }^{-}$and base excess were not affected by experimental diets indicating that all cows were acidbase balanced.

Urinary $\mathrm{pH}$ was significantly lower $(\mathrm{P}<0.0 \mathrm{l})$ in the low $\mathrm{DCAB}$ diet prepartum than other treatments and its was lower $(\mathrm{P}<0.05)$ for second parity than older cows (Table 4). All other parameters measured from urine were unaffected by age. In the K-supplemented group, urinary $\mathrm{pH}$ was lower than in the other treatment groups after parturition, although the difference was not statistically significant. Urinary $\mathrm{FE} \%$ of $\mathrm{Mg}$ and $\mathrm{Na}$ were markedly lower $(\mathrm{P}<0.01)$ prepartum in cows fed $\mathrm{K}$-supplement compared with cows fed the other experimental diets. Urinary $\mathrm{K}$ excretion was higher $(\mathrm{P}<0.05)$ and urinary $\mathrm{FE} \%$ of $\mathrm{K}$ tended to be higher in the $\mathrm{K}$-supplement group relative to other treatment groups prepartum (Table 4). Neither urinary excretion of $\mathrm{Ca}, \mathrm{P}$ and $\mathrm{Na}$, nor urinary $\mathrm{FE} \%$ of $\mathrm{Ca}$ and $\mathrm{P}$ were significantly influenced by treatments prepartum. All parameters measured from urine peripartum were unaffected by treatments.

\section{DISCUSSION}

Current results imply that a high dietary $\mathrm{K}$ content during the dry period may have a negative effect on $\mathrm{Mg}$ metabolism in the beginning of lactation when $\mathrm{Mg}$ secretion in milk rapidly increases. High dietary concentrations of $\mathrm{K}$ are known to inhibit Mg utilization in ruminants (Greene et al., 1983; Khorasani and Armstrong, 1990; Schonewille et al., 1997). In the current study five cows from se- 
TABLE 3

Effect of dictary cation-anion balance (DCAB) and $\mathrm{K}$ intake on mean plasma mineral concentrations

\begin{tabular}{|c|c|c|c|c|c|c|c|c|c|c|}
\hline & \multirow{2}{*}{ Factor } & \multicolumn{7}{|c|}{ Time from parturition } & \multicolumn{2}{|c|}{ Significance ${ }^{2}$} \\
\hline & & $-4 w \mathrm{k}$ & $-3 w k$ & $-2 w k$ & $-1 \mathrm{wk}$ & 0 & $+1 d$ & $+1 \mathrm{wk}$ & $\begin{array}{l}\text { prepar- } \\
\text { tum }\end{array}$ & $\begin{array}{c}\text { peripar- } \\
\text { tum }\end{array}$ \\
\hline \multirow{8}{*}{$\begin{array}{l}\text { Calcium }{ }^{2} \\
\mathrm{mmol} / \mathrm{l}\end{array}$} & Control & 1.31 & 1.29 & 1.31 & 1.31 & 1.12 & 1.15 & 1.28 & & \\
\hline & K-suppl & 1.33 & 1.29 & 1.34 & 1.29 & 1.05 & 1.16 & 1.35 & & \\
\hline & Anionic & 1.30 & 1.28 & 1.29 & 1.32 & 1.05 & 1.15 & 1.28 & & \\
\hline & $\mathrm{SEM}^{\prime}$ & 0.020 & 0.011 & 0.021 & 0.013 & 0.041 & 0.039 & 0.032 & ns & ns \\
\hline & $\begin{array}{l}\text { 2nd } \\
\text { parity }\end{array}$ & 1.30 & 1.28 & 1.30 & 1.30 & 1.13 & 1.17 & 1.29 & & \\
\hline & $>2 n d$ & & & & & & 1.17 & 1.27 & & \\
\hline & parity & 1.32 & 1.29 & 1.32 & 1.30 & 1.02 & 1.14 & 1.31 & & \\
\hline & SEM & 0.014 & 0.0074 & 0.014 & 0.010 & 0.031 & 0.030 & 0.024 & ns & ns \\
\hline \multirow{8}{*}{$\begin{array}{l}\text { Calcium } \\
\mathrm{mmol} / \mathrm{l}\end{array}$} & Control & 2.63 & 2.54 & 2.55 & 2.64 & 2.20 & 2.23 & 2.58 & & \\
\hline & K-suppl & 2.54 & 2.42 & 2.54 & 2.43 & 1.89 & 2.09 & 2.55 & & \\
\hline & Anionic & 2.55 & 2.45 & 2.47 & 2.56 & 1.94 & 2.18 & 2.53 & & \\
\hline & SEM & 0.084 & 0.064 & 0.070 & 0.073 & 0.130 & 0.092 & 0.118 & ns & ns \\
\hline & 2nd & & & & & & & & & \\
\hline & parity & 2.43 & 2.38 & 2.44 & 2.46 & 2.05 & 2.14 & 2.44 & & \\
\hline & parity & 2.71 & 2.56 & 2.60 & 2.63 & 1.97 & 2.19 & 2.67 & & \\
\hline & SEM & 0.064 & 0.048 & 0.054 & 0.056 & 0.099 & 0.070 & 0.090 & parity $^{* 3}$ & ns \\
\hline \multirow{9}{*}{$\begin{array}{l}\text { Magnesium } \\
\mathrm{mmol} / \mathrm{l}\end{array}$} & Contro! & 1.00 & 1.04 & 0.99 & 0.99 & 1.06 & 1.14 & 0.98 & & \\
\hline & K-supp! & 0.93 & 1.02 & 1.01 & 0.99 & 1.00 & 1.02 & 0.80 & & \\
\hline & Anionic & 0.97 & 1.00 & 0.97 & 0.94 & 1.01 & 1.02 & 0.90 & & \\
\hline & SEM & 0.026 & 0.028 & 0.026 & 0.032 & 0.038 & 0.046 & 0.051 & ns & ns \\
\hline & $2 n d$ & & & & & & & & & \\
\hline & parity & 0.95 & 1.00 & 0.96 & 0.94 & 1.01 & 1.09 & 0.88 & & \\
\hline & $>2 \mathrm{nd}$ & & & & & & & & & \\
\hline & parity & 0.98 & 1.04 & 1.02 & 1.00 & 1.04 & 1.03 & 0.91 & & \\
\hline & SEM & 0.019 & 0.021 & 0.020 & 0.024 & 0.029 & 0.035 & 0.039 & ns & $\mathrm{ns}$ \\
\hline \multirow{8}{*}{$\begin{array}{l}\text { Potassium } \\
\text { mmol/1 }\end{array}$} & Control & 4.25 & 4.45 & 4.30 & 4.13 & 4.00 & 4.11 & 3.87 & & \\
\hline & K-suppl & 4.09 & 4.64 & 4.46 & 4.56 & 3.80 & 4.22 & 3.97 & & \\
\hline & Anionic & 4.01 & 4.32 & 4.36 & 4.03 & 4.10 & 3.81 & 3.90 & & \\
\hline & SEM & 0.145 & 0.102 & 0.148 & 0.089 & 0.126 & 0.146 & 0.112 & ns & ns \\
\hline & 2nd & & & & & & & & & \\
\hline & $\begin{array}{l}\text { parity } \\
>\text { 2nd }\end{array}$ & 4.14 & 4.50 & 4.39 & 4.20 & 4.00 & 4.11 & 3.92 & & \\
\hline & parity & 4.09 & 4.45 & 4.35 & 4.29 & 3.93 & 3.98 & 3.91 & & \\
\hline & SEM & 0.110 & 0.078 & 0.113 & 0.068 & 0.096 & 0.111 & 0.085 & ns & ns \\
\hline
\end{tabular}

' $\mathrm{SEM}=$ standard error of means, due to unbalanced data standard errors vary. Lower value is given.

Maximum deviated at most from lower value $9.6 \%$

${ }^{2} \mathrm{P}<0.05^{*}, \mathrm{P}<0.01^{* *}, \mathrm{P}<0.001^{* * *}$

${ }^{3}$ parity $=2$ nd parity vs $>2$ nd parity 
TABLE 4

Effect of dietary cation-anion balance (DCAB) and $\mathrm{K}$ intake on mean urinary pH and mineral excretion

\begin{tabular}{|c|c|c|c|c|c|c|c|c|c|c|}
\hline & \multirow{2}{*}{ Factor } & \multicolumn{7}{|c|}{ Time from parturition } & \multicolumn{2}{|c|}{ Significance ${ }^{2}$} \\
\hline & & -4 wk & $-3 w k$ & $-2 w k$ & $-1 \mathrm{wk}$ & 0 & $+1 d$ & $+1 w k$ & $\begin{array}{l}\text { prepar- } \\
\text { tum }\end{array}$ & $\begin{array}{c}\text { peripar- } \\
\text { tum }\end{array}$ \\
\hline \multirow[t]{7}{*}{$\mathrm{pH}$ in urine } & Control & 8.24 & 8.39 & 8.33 & 8.29 & 8.31 & 8.20 & 8.29 & & \\
\hline & K-suppl & 8.25 & 8.41 & 8.41 & 8.38 & 8.30 & 7.97 & 7.81 & & \\
\hline & Anionic & 8.24 & 8.20 & 7.99 & 8.07 & 8.07 & 8.06 & 8.21 & & \\
\hline & $\mathrm{SEM}^{\prime}$ & 0.064 & 0.042 & 0.079 & 0.056 & 0.063 & 0.117 & 0.169 & anionic*? & ns \\
\hline & 2nd parity & 8.27 & 8.25 & 8.18 & 8.16 & 8.24 & 8.20 & 8.24 & & \\
\hline & $>2$ nd parity & 8.22 & 8.42 & 8.32 & 8.33 & 8.22 & 7.95 & 7.96 & & \\
\hline & SEM & 0.048 & 0.032 & 0.060 & 0.043 & 0.048 & 0.089 & 0.129 & parity* ${ }^{4}$ & ns \\
\hline \multirow[t]{4}{*}{$\mathrm{Ca} /$ creat." $^{6}$} & Control & 0.49 & 0.11 & 0.10 & 0.05 & 0.06 & 0.03 & 0.09 & & \\
\hline & K-suppl & 0.22 & 0.14 & 0.05 & 0.04 & 0.03 & 0.06 & 0.37 & & \\
\hline & Anionic & 0.43 & 0.22 & 0.13 & 0.22 & 0.03 & 0.02 & 0.25 & & \\
\hline & SEM & 0.155 & 0.060 & 0.031 & 0.030 & 0.018 & 0.012 & 0.145 & ns & $\mathrm{ns}$ \\
\hline \multirow[t]{4}{*}{$\mathrm{K} /$ creat. } & Control & 38.9 & 43.2 & 44.3 & 45.6 & 35.6 & 57.6 & 56.0 & & \\
\hline & K-supp! & 42.6 & 59.3 & 63.1 & 64.2 & 51.1 & 52.0 & 62.6 & & \\
\hline & Anionic & 59.3 & 46.8 & 46.5 & 51.8 & 36.7 & 61.7 & 60.5 & & \\
\hline & SEM & 8.79 & 4.18 & 4.13 & 3.74 & 5.62 & 5.38 & 7.63 & $\mathrm{~K}$-suppl ${ }^{*}$ & ns \\
\hline \multirow[t]{4}{*}{ Ca FE\%? } & Control & 1.96 & 0.48 & 0.46 & 0.26 & 0.37 & 0.14 & 0.41 & & \\
\hline & K-suppl & 0.96 & 0.60 & 0.17 & 0.20 & 0.17 & 0.27 & 1.12 & & \\
\hline & Anionic & 1.49 & 0.96 & 0.59 & 1.08 & 0.17 & 0.10 & 0.92 & & \\
\hline & SEM & 0.590 & 0.280 & 0.142 & 0.161 & 0.116 & 0.055 & 0.437 & ns & ns \\
\hline \multirow[t]{4}{*}{$\mathrm{Mg} \mathrm{FE} \%$} & Control & 6.85 & 11.41 & 11.47 & 9.89 & 6.60 & 9.18 & 4.67 & & \\
\hline & K-suppl & 4.45 & 7.48 & 6.26 & 6.23 & 2.45 & 3.50 & 7.00 & & \\
\hline & Anionic & 9.08 & 12.05 & 10.62 & 11.74 & 4.54 & 4.76 & 5.69 & & \\
\hline & SEM & I. 195 & 1.287 & 1.440 & 1.729 & 1.209 & 1.098 & 1.374 & K-suppl." & ns \\
\hline \multirow[t]{4}{*}{ K FE\% } & Control & 89.1 & 102.7 & 119.6 & 135.0 & 112.4 & 162.1 & 155.5 & & \\
\hline & K-suppl & 102.3 & 128.5 & 146.0 & 165.9 & 158.4 & 127.2 & 142.2 & & \\
\hline & Anionic & 128.6 & 105.0 & 108.4 & 142.7 & 102.1 & 168.1 & 136.0 & & \\
\hline & SEM & 16.42 & 9.13 & 8.39 & 12.37 & 13.07 & 12.18 & 18.72 & parily ${ }^{*}$ & ns \\
\hline \multirow[t]{4}{*}{$\mathrm{Na} \mathrm{FE} \%$} & Control & 6.85 & 11.41 & 11.47 & 9.89 & 6.60 & 9.18 & 4.67 & & \\
\hline & K-suppl & 4.45 & 7.48 & 6.26 & 6.23 & 2.45 & 3.50 & 7.00 & & \\
\hline & Anionic & 9.08 & 12.05 & 10.62 & 11.74 & 4.54 & 4.76 & 5.69 & & \\
\hline & SEM & 1.195 & 1.287 & 1.440 & 1.729 & 1.209 & 1.098 & 1.374 & K-suppl. ${ }^{* *}$ & ns \\
\hline
\end{tabular}

SEM = standard error of means, due to unbalanced data standard errors vary. Lower value is given.

Maximum deviated at most from lower value $9.6 \%$

${ }^{2} \mathrm{P}<0.05^{*}, \mathrm{P}<0.01 * *, \mathrm{P}<0.001^{* * *}$

${ }^{3}$ Tukey; anionic salts vs other treatments

${ }^{4}$ parity $=2$ nd parity $v s>2$ nd parity

${ }_{5}^{5}$ Tukey; K-supplement vs. other treatments

$6=\mathrm{mmol} / \mathrm{mmol}$

$7=$ fractional excretion 
ven had subclinical hypomagnesaemia one week after parturition in the K-supplemented group. Such an observation was unexpected since the K-supplement had already been removed at parturition and the $\mathrm{Mg}$ content of prepartum diets was relatively high $(4.1 \mathrm{~g} \mathrm{Mg} / \mathrm{kg} \mathrm{DM})$. In addition, all cows received the same feeds after calving which composed of a commercial concentrate and mineral mix fed according to milk yield and grass silage ad libitum. However, $\mathrm{K}$ is the most abundant intracellular cation, and it is possible that during supplementation, $\mathrm{K}$ was transiently stored intracellularly. After calving when the feeding was changed, it is likely that there is a lag time associated with the redistribution of $\mathrm{K}$ between extracellular and intracellular fluid.

One cow in the K-supplement group showed clinical signs of parturient hypocalcaemia and another had low $\mathrm{Ca}^{2+}$ status since blood $\mathrm{Ca}^{2+}$ concentrations were below $1.00 \mathrm{mmol} / \mathrm{l}$ (Radostits et al., 1994). These findings are consistent with the study of Goff and Horst (1997) who demonstrated that dictary K intake was associated with a predisposition to parturient hypocalcaemia. In the current experiment dietary content of control, K-supplemented and anionic treatments were 24, 34 and $25 \mathrm{~g} / \mathrm{kg} \mathrm{DM}$, respectively. According to Goff and Horst (1997) the level of $\mathrm{K}$ in the control group should have lead to a predisposition to hypocalcaemia, but no incidences were observed. These findings cannot be explained by age, a factor known to increase the risk of hypocalcaemia (Radostits et al., 1994), since all experimental animals were relatively young.

Cows in the $\mathrm{K}$-supplemented group tended to have higher plasma $\mathrm{K}$ concentrations during the study and excreted significantly $(\mathrm{P}<0.05)$ more $\mathrm{K}$ in the urine than the other groups. Supplementation with $\mathrm{K}$ caused a significant $(\mathrm{P}<0.01)$ renal conservation of $\mathrm{Mg}$ and $\mathrm{Na}$, since $\mathrm{FE} \%$ of $\mathrm{Mg}$ and $\mathrm{Na}$ was lower relative to other treatment groups. It is likely that $\mathrm{Na}$ is conserved by the secretion of aldosterone and that the subsequent increase in tubular reabsorption of $\mathrm{Na}$ in the kidney leads to an increase in $\mathrm{K}$ excretion. Increased diuresis has been observed in cows fed $\mathrm{KCl}$ at the rate of $1.5 \mathrm{~g} / \mathrm{kg}$ body weight (Deetz et al., 1982).

Urinary $\mathrm{pH}$ was significantly lower $(\mathrm{P}<0.01)$ for cows fed the low DCAB prepartum compared with the other treatments, indicating a rapid renal recognition of the excessive dietary acid load. This finding is consistent with earlier studies where the acid-base status of dry cows could be modified even within the positive DCAB range, although no effects on urinary mineral excretion were observed (Delaquis and Block, 1995). Acidification must be stronger since no changes in blood $\mathrm{Ca}^{2+}$ were noticed. In the present study, urinary $\mathrm{pH}$ decreased for the K-supplemented group after parturition compared with other treatment groups, but the reason for this phenomena remains unclear.

In the current study we offered cautiously anionic salts not to modify the palatability of experimental diets. As a result, even the low DCAB remained positive $(+107 \mathrm{mEq} / \mathrm{kg} \mathrm{DM})$ and ionized $\mathrm{Ca}$ in blood, total $\mathrm{Ca}$ in plasma and 
urinary $\mathrm{Ca}$ excretion were unaffected. Futhermore, two from seven cows had low ionized $\mathrm{Ca}$ concentrations at parturition. DCAB should be under $-30 \mathrm{mEq} /$ $\mathrm{kg}$ DM to affect acid-base status and subsequently improve Ca metabolism (Tucker et al., 1992). Using a daily dose of $3 \mathrm{Eq}$ of anionic salts per cow as recommended by Oetzel (1993), the DCAB would have been $-67 \mathrm{mEq} / \mathrm{kg}$ DM.

Poor palatability is a potential problem with anionic concentrate mixtures. In the current study a daily intake of $1.8 \mathrm{Eq}$ of anionic salts was shown to have no detrimental effects on intake. According to Oetzel et al. (1991), the amount of anionic salts $(\mathrm{Eq} /$ day) could be higher since an intake of anionic salts $(2 \mathrm{Eq} / \mathrm{d})$ maintained intake, but at higher levels of $2.3 \mathrm{Eq} /$ day a dramatic decrease in the acceptability of the concentrate mixture was noticed (Oetzel and Barmore, 1993). However, anionic salt intake does not fully explain the effects on intake, since a daily intake of 3.2 Eq has in some (Tauriainen et al., 1998a) but not all cases (Tauriainen et al., 1998b,c) had detrimental effects. It is likely that there are factors other than the amount anionic salt equivalents that effect the palatability of a concentrate mixtures. In the present study, palatability could be improved by the inclusion of wheat molasses in the concentrate mixture to disguise the bitter taste of anionic salts. Futhermore, the odorous substance of coconut also encouraged the cows to eat.

Udder ocdema has been evaluated using a subjective categorical scoring from 1 to 5 (Randall et al., 1974; Dentine and McDaniel, 1983; Nestor et al., 1988). We tested a quantitative method to measure udder oedema. It appears that this approach requires simultaneous evaluation with the subjective method, since in some cows the oedema appeared to spread cranially under the abdomen, a phenomena which could not be taken into account in quantitative measurements. Two weeks before the expected calving date would be a more suitable time to start the evaluation of udder oedema since 4 weeks before expected parturition was too early.

In conclusion, the palatability of concentrate mixtures was not depressed by the presence of anionic salts, although their inclusion had no effect on Ca metabolism of dry cows. The target for effective DCAB should be below $-30 \mathrm{mEg} / \mathrm{kg}$ DM. Increases in $\mathrm{Mg}$ intake from recommended levels of $17 \mathrm{~g} / \mathrm{d}$ to $33 \mathrm{~g} / \mathrm{d}$ appeared to be beneficial since only one cow had a plasma Mg concentration below $0.85 \mathrm{mmol} / \mathrm{l}$ at parturition. However, a dietary K concentration of $34 \mathrm{~g} / \mathrm{kg}$ DM coupled with a high $\mathrm{Mg}$ intake of $4 \mathrm{~g} / \mathrm{kg}$ DM in the prepartum diet may negatively effect $\mathrm{Mg}$ metabolism after parturition. This phenomenon should be noted under practical conditions whenever $\mathrm{K}$ intake of cows is changed. 


\section{ACKNOWLEDGEMENTS}

The authors would like to thank for the technical assistance of Juha Suomi, Anne Kallio, Marjo Oikarinen, Miia Nyrhilä, Lilja Jääskeläinen and Juhani Taponen. Co-operation with Merja Holma is gratefully acknowledged.

\section{REFERENCES}

Abu Damir H., Phillippo M., Thorp B.H., Milne J.S., Dick L., Nevison I.M., 1994. Effects of dietary acidity on calcium balance and mobilisation, bone morphology and 1,25 dihydroxyvitamin $D$ in prepartal dairy cows. Res. Vet. Sci. 56,310-318

AOAC, 1984. Official Methods of Analysis. Association of Official Analytical Chemists, Inc. Arlington, Virginia

Block E., 1984. Manipulating dictary anions and cations for prepartum dairy cows to reduce incidence of milk fever. J. Dairy Sci. 67, 2939-2948

Daly J.A., Ertigshausen G., 1972. Direct method for determining inorganic phosphate in serum with the „CentriChem”. Clin. Chem. 18, 263-265

Deetz L.E., Tucker R.E., Mitchell G.E.Jr., DeGregorio R.M., 1982. Renal function and magnesium clearance in young and old cows given potassium chloride and sodium sitrate. J. Anim. Sci. 55, 680-689

Delaquis A.M., Block E., 1995. Acid-base status, renal function, water, and macromineral metabolism of dry cows fed diets differing in cation-anion balance. J. Dairy Sci. 78, 604-619

Dentine M.R., McDaniel B.T., 1983. Variation of edema scores from herd-year, age, calving month, and sire. J. Dairy Sci. 66, 2391-2399

Fabiny D.L., Ertigshausen G., 1971. Automated reaction rate method for determination of serum creatinine with Centrifichem. Clin. Chem. 17, 696-700

Goff J.P., Horst R.L., Mueller F.J., Miller J.K., Kicss G.A., Dowlen H.II., 1991. Addition of chloride to a prepartal diet high in cations increases 1,25 -dihydroxyvitamin $D$ response to hypocalcaemia preventing milk fever. J. Dairy Sci. 74, 3863-3871

Goff J.P., Horst R.L., 1997. Effects of the addition of potassium or sodium, but not calcium, to prepartum rations on milk fever in dairy cows. J. Dairy Sci, 80, 176-186

Greene L.W., Fontenot J.P., Webb K.E. Ir., 1983. Site of magnesium and other macromineral absorption in steers fed high levels of potassium. J. Anim. Sci. 57, 503-510

Khorasani G.H., Armstong D.G., 1990. Effect of sodium and potassium level on the absorption of magnesium and other macrominerals in sheep. Livest. Prod. Sci. 24, 223-235

Kiess G.A., Miller J.K., Ramscy N., Mueller F.J., Zanzalari K.P., Holmes C.R., 1987. Incidence and severity udder edema in primigravid beifers fed different amounts and rations of sodium and chlorine. J. Dairy Sci. 70, 179 (Abstr.)

Lema M., Tucker W.B., Aslam M., Shin I.S., Le Ruyet P., Adauns G.D., 1992. Iniluence of calcium chloride fed prepartum on severity of edema and lactational performance of dairy heifers. J. Dairy Sci. 75, 2388-2393

MAFF, 1975. Energy Allowances and Fecding Systems for Ruminants. Ministry of Agriculture, Fisheries and Food. Tech. Bull. 33, London, HMSO

Nestor K.E. Jr.. Hemken R.W., Harmon R.J., 1988. Influence of sodium chloride and potassium bicarbonate on udder edema and selected blood parameters. J. Dairy Sci. 71, 366-372 
Nousiainen J., 2000. Personal information. Valio Ltd., Finland

Oetzel G.R., 1993. Use of anionic salts for prevention of milk fever in dairy cattle. Compendium 15 , $1138 \cdot 1146$

Oetzel G.R., Barmore J.A., 1993. Intake of concentrate mixture containing various anionic salts fed to pregnant, non-lactating dairy cows. J. Dairy Sci. 76, 1617-1623

Octzel G.R., Fettman M.J., Hamar D.W., Olson J.D., 1991. Screening of anionic salts for palatability, effects on acid-base status and urinary calcium excretion in dairy cows. J. Dairy Sci. $74,965-971$

Oetzel G.H, Olson J.D., Curtis C.R., Fettman M.J., 1988. Ammonium chloride and ammonium sulphate for prevention of parturient paresis in dairy cows. J. Dairy Sci. 71, 3302-3309

Phillippo M., Reid G.W., Nevison I.M., 1994. Parturient hypocalcaemia in dairy cows, Effects of dictary acidity on plasma minerals and calciotrophic hormones. Res. Vet. Sci, 56, 303-309

Radostits O.M., Blood D.C., Gay C.G., 1994. Parturient paresis. In: Veterian Medicine. 8th Edition. Baillicre Tindal, London, pp. 1314-1328

Randall W.E., Hemken R.W., Bull L.S., Douglas L.W., 1974. Effect of dietary sodium and potassium on udder edema in Holstein heifers. J. Dairy Sci. 57, 472-475

Samson B.F., Manston R., Vagg M.J., 1983. Magnesium and milk fever. Vet. Rec. 112, 447-449

SAS, 1985. SAS User's Guide, Statistics. 5th Edition. SAS Institute Inc. Cary, NC

Schonewille J.Th., Klooster van't A.T., Wouterse H., Beynen A.C., 1999. Effects of intrinsic potassium in artifically dried grass and supplemental potassium bicarbonate on apparent magnesium absorption in dry cows. J. Dairy Sci. 82, 1824-1830

Schonewille J.Th., Ram L., Klooster van't A.Th., Wouterse H., Beynen A.C., 1997. Intrinsic potassium in grass silage and magnesium absorption in dry cows. Livest. Prod. Sci. 48, 99-110

Tauriainen S., Sankari S., Pyörälä S., Syrjälä-Qvist L., 1998a. Effect of anionic salts in concentrate mixture and calcium intake on some blood and urine minerals, acid-base balance and feed intake of dry pregnant cows on grass silage based feeding. Agr. Food Sci. Finland 7, 523-533

Tauriainen S., Sankari S., Pyörälä S., Syrjälä-Qvist L., 1998b. Effect of anionic salts in concentrate mixture and magnesium intake on some blood and urine minerals, acid-base balance and feed intake of dry pregnant cows on grass silage based feeding. Agr. Food Sci. Finland 7, 535-543

Tauriainen S., Sankari S., Syrjälä-Qvist L., 1998c. Effect of anionic salts in concentrate mixture on some blood and urine minerals, acid-base balance and feed intake of dry pregnant cows on grass silage based feeding with high calcium intakc. Agr. Food Sci. Finland 7, 545-552

Tucker W.B., Hogue J.F., Adams G.H., Aslam M., Shin I.S., Morgan G., 1992. Influence of dietary cation-anion balance during the dry period on the occurrence of parturient paresis in cows fed excess calcium. J. Anim. Sci. 70, 1238-1250

Tucker W.B., Hogue J.F., Waterman D.F., Swenson T.S., Xin Z., Hemken R.W., Jackson J.A., Adams G.D., Spicer L.J., 1991. Role of sulfur and chloride in the dictary cation- anion balance equation for lactating dairy cattle. J. Anim. Sci. 69, 1205-1213

Tuori M., Kaustell K., Valaja J., Aimonen E., Saarisalo E., Huhtanen P., 1996. Feed Tables and Feeding Recommendations (in Finnish). $2^{\text {nd }}$ Edition. Helsinki, pp. 99

Wang C., Beede D.K., 1992. Effects of ammonium chloride and sulphate on acid-base status and calcium metabolism of dry Jersey cows. J. Dairy Sci. 75, 820-828

Windman E.E., Jones G.M., Wagner P.E., Boman R.L., Troutt H.F.Jr, Lesch T.N., 1982. A dairy cow body condition scoring system and its relationship to selected production characteristics. J. Dairy Sci. 65, 495-501 


\section{STRESZCZENIE}

Wplyw podania soli anionowych i potasu na zawartość niektórych skladników mineralnych w krwi i moczu oraz równowagę kwasową u zasuszonych cielnych krów żywionych kiszonką $\mathrm{z}$ traw

Dwadzieścia jeden krów Ayshire podzielono losowo na 3 grupy żywicniowe celem zbadania wplywu soli anionowych oraz pobrania wysokich dawek potasu $(\mathrm{K})$ na przemianę mineralną, równowagę kwasową i pobranie paszy przez zasuszone krowy otrzymujące kiszonkę z traw jako paszę podstawową. Bilans kationowo-anionowy (DCAB), obliczony w milirównoważnikach $\left[\left(\mathrm{Na}^{+}+\mathrm{K}^{+}\right)-\right.$ $\left(\mathrm{Cl}^{-}+\mathrm{S}^{2-}\right)$ ] przy wysokim DCAB (kontrola), wysokim DCAB z dodatkiem $\mathrm{K}$ (jako $\mathrm{KHCO}_{3}$ ) oraz niskim DCAB wynosił $+298,+571 \mathrm{j}+107 \mathrm{mEq} / \mathrm{kg}$ s.m., odpowiednio. Zawartość magnezu $(\mathrm{Mg}) \mathrm{w}$ dawce, odpowiadająca $33 \mathrm{~g}$ dziennego pobrania $\mathrm{Mg}$, wynosiła średnio $0,4 \% \mathrm{w}$ s.m.. Krowy otrzymywały kiszonkę z traw $(5,2 \mathrm{~kg} \mathrm{s.m}$.), siano $(0,9 \mathrm{~kg} \mathrm{s.m}$.) i mieszankę treściwą $(2,7 \mathrm{~kg} \mathrm{s.m}$.) aż do ocielenia. Próby krwi i moczu pobierano 4, 3, 2 i l-go tygodnia przed spodziewaną datą wycielenia, przy wycieleniu oraz l-go dnia tydzień po wycieleniu. Podawanie dawki $z$ niskim bilansem DCAB wpłynçło istotnic tylko na $\mathrm{pH}$ moczu przed wycieleniem. Dodatek K obniżał wydalanie w moczu Mg i $\mathrm{Na}$, a istotnie zwiększał wydalanie K do czasu wyciclenia. D7ienna dawka K, $34 \mathrm{~g} / \mathrm{kg}$ s.m., w połączeniu z wysokim pobranicm $\mathrm{Mg}, 4 \mathrm{~g} / \mathrm{kg}$ s.m., w okresie przed wycieleniem, wpłynçia ujemnie na przemianę $\mathrm{Mg}$ po wycieleniu. 